\title{
Comparative nutritional and functional properties of selected underutilized legumes
}

${ }^{* 1}$ Soetan, K. O. and ${ }^{2}$ Adeola, A. A.

1. Department of Veterinary Physiology and Biochemistry, Faculty of Veterinary Medicine, University of Ibadan, Ibadan.

2. Institute of Food Security, Environmental Resources and Agricultural Research, (2) Federal University of Agriculture, Abeokuta.

*Corresponding author: kehinde.soetan@gmail.com; 08074437629

\section{Abstract}

$\overline{\text { Underutilized and neglected legumes have numerous nutritional potentials with great }}$ contributions to food security but they are usually excluded from research and development agenda. This study evaluates the nutritional and functional properties of six different underutilized and neglected legumes; Lima bean (LB) (Phaseolus lunatus) (2006-009), Bambara groundnut (BG) (Vigna subterranea) (TVSU- 1482), winged bean (WB) (Psophocarpus tetragonolobus) (Tpt-48), jack bean (JB) (Canavalia ensiformis) (Tce-4), sword bean (SB) (Canavalia gladiata) (Tcg-4) and African yam bean (AYB) (Sphenostylis stenocarpa) (TSS-95) from the Genetic Resources Unit (GRU), International Institute of Tropical Agriculture (IITA), Ibadan, Oyo State, Nigeria. Nutritional and functional properties were evaluated using proximate composition, mineral analyses and functional properties like bulk density, water absorption capacity, oil absorption capacity, emulsion capacity and dispersibility. All the procedures were carried out using standard protocols. Statistical analysis was done using descriptive statistics. Results of proximate analysis showed that crude protein ranged from $18.88 \pm 0.15 \%$ (WB) to $26.60 \pm 0.14 \%$ (AYB), crude fat ranged from $1.84 \pm 0.02 \%(\mathrm{JB})$ to $6.39 \pm 0.03 \%(B G)$, crude fibre ranged from $3.70 \pm 0.00 \%$ $(A Y B)$ to $5.04 \pm 0.03 \%(S B)$, ash ranged from $3.10 \pm 0.14 \%(A Y B)$ to $4.66 \pm 0.02 \%(L B)$, nitrogen free extract ranged from $55.60 \pm 0.04 \%(S B)$ to $62.97 \pm 0.12 \%(W B)$, moisture content ranged from $5.75 \pm 0.48 \%$ ( $A Y B)$ to $10.77 \pm 0.03 \%(\mathrm{JB})$, dry matter ranged from $89.23 \pm 0.03 \%(J B)$ to $94.25 \pm 0.488 \%(A Y B)$ and gross energy ranged from $4.39 \pm 0.003$ $\mathrm{kcal} / \mathrm{g}(\mathrm{SB})$ to $4.66 \pm 0.00(B G)$. Mineral content results revealed that calcium varied from $0.14 \pm 0.000 \%$ ( $L B$ ) to $0.23 \pm 0.0003 \%$ ( $A Y B)$, phosphorus varied from $0.20 \pm 0.0001 \%$ ( $A Y B)$ to $0.38 \pm 0.00 \%(B G)$, sodium varied from $0.12 \pm 0.00 \%$ ( $L B$ and $W B)$ to $0.35 \pm 0.0006 \%$ $(A Y B)$, potassium varied from $0.69 \pm 0.00 \%(L B)$ to $1.12 \pm 0.00 \%(B G)$, magnesium varied from $0.15 \pm 0.0002 \%(A Y B)$ to $0.27 \pm 0.000 \%(B G)$ and iron varied from $44.84 \pm 0.03(\mathrm{mg} / \mathrm{g})$ (WB) to 80.98+0.0007( $\mathrm{mg} / \mathrm{g})(A Y B)$. Results of functional properties showed that bulk density ranged from $0.45 \pm 0.04 \mathrm{~g} / \mathrm{mL}(W B)$ to $0.77 \pm 0.08 \mathrm{~g} / \mathrm{mL}(\mathrm{SB})$, water absorption capacity ranged from $168.33 \pm 0.03 \mathrm{~g} / 100 \mathrm{~g}(\mathrm{LB})$ to $183.62 \pm 0.01 \mathrm{~g} / 100 \mathrm{~g}(\mathrm{SB})$, oil absorption capacity ranged from $146.54 \pm 0.02 \mathrm{~g} / 100 \mathrm{~g}(\mathrm{LB})$ to $161.55 \pm 0.02 \mathrm{~g} / 100 \mathrm{~g}(\mathrm{JB})$, emulsion capacity ranged from $79.67 \pm 0.02 \mathrm{~g} / 100 \mathrm{~g}(\mathrm{LB})$ to $89.46 \pm 0.02 \mathrm{~g} / 100 \mathrm{~g}(\mathrm{SB})$ and dispersibility ranged from $81.0 \pm 1.41 \%$ ( $S B$ ) to $86.5 \pm 0.71 \%(B G)$.

The study concluded that all the underutilized legumes have varying nutritional and functional properties, which should be exploited for nutritional benefits and industrial applications, as a solution to the problem of food shortage, especially in the developing countries.

Keywords: Underutilized legumes, nutritional, functional, food security 


\section{Comparative nutritional and functional properties of selected underutilized legumes}

\section{Introduction}

Legumes belong to the Family leguminacea which are large and economically important family of plants (Gept et al., 2005; Ojo, 2013). They include a large number of domesticated species harvested as crops for human and animal consumption. Leguminous plants play very critical roles in human and animal nutrition. They provide a significant amount of food in developing countries. Legumes are the richest sources of plant proteins, providing about $10 \%$ of the total dietary requirements of the proteins world over (Asif et al., 2013). They are important sources of protein, fibre, complex carbohydrates (a strong case for glycemic index foods), iron, and zinc in the diet (Roba et al., 2015). According to Roba et al. (2015) legumes, as protein source, are more desirable (cost-wise) than animal source foods in developing countries. In combination with cereal, legumes can supply the amino acids required for growth and development (Roba et al., 2015). Consumption of legumes has been reported to reduce the incidence of coronary heart disease (Asif et al., 2013). Legumes are utilised in many food formulations such as bakery products, bread, pasta, snack foods, soups, cereal bar filing, tortillas, meat, etc. (Asif et al., 2013).

Global food security is being greatly threatened as a result of increasing overdependence on a few major staple crops, leading to an alarming reduction in crop diversity and variability, especially the neglected and underutilized species (Ikhajiagbe and Mensah, 2012). However, variability is an important factor to consider in crop improvement programmes (Akinyosoye et al., 2017). Neglected and underutilised species (NUS) are indigenous, relatively common, available, accessible, well-adapted, easy and cheapto-produce crops (Okigbo, 1973; Padulosi et al., 2003; Oniang'o et al., 2006; Jaenicke and Pasiecznik, 2009; Ojo et al., 2016). NUS possess numerous nutritional potentials (Adewale and Aremu, 2013).Underutilized species are usually not recognised by policy makers probably because their economic value is not apparent (Stifel, 1990) and hence NUS are excluded from the research and development agenda of academic and research institutions. Underutilized crops are important as household food and they contribute significantly to food security (Naylor et al., 2004; Oniang'o et al., 2006).

Lima bean (LB) (Phaseolus lunatus) belongs to the family leguminosae and is mostly cultivated in South America (Yellavila et al., 2015). Lima beans are sometimes referred to as: haba beans, sugar beans, butter beans, Guffin beans, civet beans, Hibbert beans, Pallar beans, Sieva beans, Madagascar beans, and Burma beans (Yellavila et al., 2015).

Bambara groundnut (BG) [Voandzeia subterranean (L) Thouars] originated in Africa origin used locally as a vegetable (Ayo et al., 2014). According to Ayo et al. (2014) it is known by different names in Nigeria such as 'Gurjiya or Kwaruru' (Hausa tribe), 'Kwam' (Geom, Plateau State), 'Okpa' (Ibo tribe) and 'Epakuta' (Yoruba tribe). Bambara groundnut can be consumed in different forms (either at immature green or mature stages) as a vegetable and it is capable boosting food availability and improving malnutrition (Ayo et al., 2014).

Winged bean (WB) (Psophocarpus tetragonolobus), an under-exploited legume, is a potential food source for the tropics (Amoo et al., 2006). It is unique among leguminous crops in that, several parts of the plant: leaves, pods, seeds and tubers: are edible and rich in protein (Amoo etal., 2006).

Jack bean (JB) (Canavalia ensiformis) is one of the under exploited tropical dry 


\section{Soetan and Adeola}

beans which is widely distributed in Africa, Asia, the West Indies, Latin America and India (Marimuthu and Gurumoorthi, 2013). Raw Jack bean seed contains about $300 \mathrm{~g} \mathrm{~kg}^{-1}$ protein and $600 \mathrm{~g} \mathrm{~kg}^{-1}$ carbohydrates (Marimuthu and Gurumoorthi, 2013).

Sword bean (SB) (Canavalia gladiata) belongs to the Pea family: Fabaceae and originated either from southern Asia or Africa (Adebowale et al., 2006). Sword bean possesses good agronomic properties which make it resilient to adverse climate change, and thus desirable for improving food and nutrition security in the tropics (Adebowale et al., 2006).

African yam bean (AYB) (Sphenostylis stenocarpa), a lesser-known legume of the tropical and sub -tropical areas of the world, is gaining prominence in research (Obasi et al., 2012). It has been claimed to be useful in the management of chronic diseases like diabetes, hypertension, and cardiovascular diseases due to its high dietary fibre content (Obasi et al., 2012).

International Institute of Tropical Agriculture (IITA) in its pursuit of nourishing Africa continues to come up with different accessions of legumes, through its Genetic Resources Unit (GRU). The agronomic features of these new varieties of legumes have been determined. The literature is scanty on the chemical and functional properties of these new varieties. This paper therefore intends to provide information on the proximate composition, mineral constituents and functional properties of selected underutilized and lesser-known legumes.

\section{Materials and methods \\ Source of the underutilized legumes}

All the underutilized legumes; Lima bean (2006-009), bambara groundnut (TVSU1482), winged bean (Tpt-48), jack bean (Tce-4), sword bean (Tcg-4) and African yam bean (TSS-95) were obtained from the Genetic Resources Unit (GRU), International Institute of Tropical Agriculture (IITA), Ibadan, Oyo State, Nigeria.

Preparation offlour samples

All the dried underutilized legume seeds were separately crushed into powdery forms with the use of an electric blender (Blender/Miller III, model MS-223, Taiwan, China).

Determination of proximate composition and energy content of flour samples of the legumes

The proximate composition of the legume samples (ash, crude fat (ether extract), crude fiber, moisture, dry matter and gross energy) were determined using (AOAC, 2000). The total nitrogen (N) was measured using macro Kjeldahl apparatus and crude protein content in the sample was calculated using the formular $\mathrm{N} \times 6.25$. Crude fat (ether extract) content was determined using soxhlet apparatus.

Determination of mineral composition of flour samples of the legumes

The mineral analysis was performed with the method of AOAC (2000). The minerals tested were calcium $(\mathrm{Ca})$, phosphorus $(\mathrm{P})$, sodium $(\mathrm{Na})$, potassium $(\mathrm{K})$, magnesium $(\mathrm{Mg})$ and iron $(\mathrm{Fe}) . \mathrm{Na}, \mathrm{K}$ and $\mathrm{Ca}$ were determined by flame photometry while $\mathrm{Mg}$, $\mathrm{P}, \mathrm{Fe}$ and $\mathrm{Cu}$ were determined using atomic absorption spectroscopy.

Determination of functional properties of flour samples of the legumes

Bulk density was determined according to the method of Wang and Kinsella (1976). Water absorption capacity was determined by the method of Nwosu et al. (2010). Oil absorption capacity was determined according to the method of Onwuka (2005). Emulsifying capacity was determined according to the method of Coffman and Garcia (1977). Dispersibility was determined according to the method 


\section{Comparative nutritional and functional properties of selected underutilized legumes}

described by Kulkarni et al. (1991).

\section{Results}

The results of the proximate composition and gross energy content of the selected underutilized legumes are in Table 1.

Crude protein ranged from $18.88 \pm 0.15 \%$ (WB) to $26.60 \pm 0.14 \%$ (AYB), crude fat ranged from $1.84+0.02 \% \quad(J B)$ to $6.39 \pm 0.03 \%(B G)$, crude fibre ranged from
$3.70 \pm 0.00 \%$ (AYB) to $5.04 \pm 0.03 \%$ (SB), ash ranged from $3.10 \pm 0.14 \%(\mathrm{AYB})$ to $4.66 \pm 0.02 \%$ (LB), nitrogen free extract ranged from $55.60+0.04 \%(\mathrm{SB})$ to $62.97 \pm 0.12 \%$ (WB), moisture content ranged from $5.75 \pm 0.48 \%$ (AYB) to $10.77 \pm 0.03 \%(\mathrm{JB})$, dry matter ranged from $89.23+0.03 \%(\mathrm{JB})$ to $94.25 \pm 0.488 \%$ (AYB) and gross energy ranged from $4.39 \pm 0.003 \mathrm{kcal} / \mathrm{g}(\mathrm{SB})$ to $4.66 \pm 0.00(\mathrm{BG})$.

\begin{tabular}{|c|c|c|c|c|c|c|c|c|}
\hline Varieties & $\begin{array}{c}\text { Crude } \\
\text { Protein }\end{array}$ & $\begin{array}{c}\text { Crude } \\
\text { fat }\end{array}$ & $\begin{array}{l}\text { Crude } \\
\text { fibre }\end{array}$ & Ash & Moisture & $\begin{array}{c}\text { Dry } \\
\text { Matter }\end{array}$ & $\begin{array}{c}\text { Nitrogen } \\
\text { free } \\
\text { extract }\end{array}$ & $\begin{array}{c}\text { Gross } \\
\text { energy }\end{array}$ \\
\hline $\begin{array}{l}\text { Lima beans } \\
(2006-009)\end{array}$ & $19.98 \pm 0.13$ & $2.21 \pm 0.03$ & $4.75 \pm 0.02$ & $4.66 \pm 0.02$ & $8.77 \pm 0.03$ & $91.23 \pm 0.03$ & $59.64 \pm 0.07$ & $4.41 \pm 0.00$ \\
\hline $\begin{array}{l}\text { Bambara } \\
\text { groundnut } \\
\text { (TVSU-1482) }\end{array}$ & $21.14 \pm 0.08$ & $6.39 \pm 0.03$ & $4.54 \pm 0.02$ & $4.00 \pm 0.04$ & $7.81 \pm 0.03$ & $92.19 \pm 0.03$ & $56.13 \pm 0.04$ & $4.66 \pm 0.00$ \\
\hline $\begin{array}{l}\text { Winged bean } \\
\text { (Tpt-48) }\end{array}$ & $18.88 \pm 0.15$ & $1.95 \pm 0.02$ & $3.87 \pm 0.02$ & $4.13 \pm 0.02$ & $8.23 \pm 0.05$ & $91.78+0.05$ & $62.97 \pm 0.12$ & $4.42 \pm 0.00$ \\
\hline $\begin{array}{l}\text { Jack bean } \\
\text { (Tce- } 4)\end{array}$ & $21.73 \pm 0.08$ & $1.84 \pm 0.02$ & $4.73 \pm 0.02$ & $3.99 \pm 0.04$ & $10.77 \pm 0.03$ & $89.23 \pm 0.03$ & $56.95 \pm 0.06$ & $4.41 \pm 0.003$ \\
\hline $\begin{array}{l}\text { Sword bean } \\
\text { (Tcg-4) }\end{array}$ & $22.84 \pm 0.08$ & $2.10 \pm 0.02$ & $5.04 \pm 0.03$ & $4.27 \pm 0.02$ & $10.17 \pm 0.02$ & $89.84 \underline{+0.02}$ & $55.60 \pm 0.04$ & $4.39 \pm 0.003$ \\
\hline $\begin{array}{l}\text { African yam } \\
\text { bean } \\
\text { TSS-95 }\end{array}$ & $\begin{array}{l}26.60 \\
\pm 0.14\end{array}$ & $3.00 \pm 0.14$ & $3.70 \pm 0.00$ & $3.10 \pm 0.14$ & $5.75 \pm 0.48$ & $94.25 \pm 0.48$ & $57.85 \pm 0.02$ & $4.558 \pm 0.01$ \\
\hline
\end{tabular}

The Mineral constituents of the selected underutilized legumes are in Table 2. Calcium varied from $0.14 \pm 0.000 \%$ (LB) to $0.23 \pm 0.0003 \%$ (AYB), phosphorus varied from $0.20 \pm 0.0001 \%$ (AYB) to $0.38 \pm 0.00 \%$ (BG), sodium varied from $0.12 \pm 0.00 \%$ (LB

and $\mathrm{WB}$ ) to $0.35 \pm 0.0006 \%$ (AYB), potassium varied from $0.69 \pm 0.00 \%$ (LB) to $1.12 \pm 0.00 \%(\mathrm{BG})$, magnesium varied from $0.15+0.0002 \%$ (AYB) to $0.27 \pm 0.000 \%$ (BG) and iron varied from $44.84 \pm 0.03$ $(\mathrm{mg} / \mathrm{g})$ (WB) to $80.98 \pm 0.0007(\mathrm{mg} / \mathrm{g})$ (AYB).

Table 2: Mineral constituents of selected underutilized legumes

\begin{tabular}{|c|c|c|c|c|c|c|}
\hline Varieties & $\%$ Calcium & $\begin{array}{l}\% \\
\text { Phosphorus }\end{array}$ & $\begin{array}{l}\% \\
\text { Sodium }\end{array}$ & \% Potassium & $\begin{array}{l}\% \\
\text { Magnesium }\end{array}$ & Iron $(\mathrm{mg} / \mathrm{g})$ \\
\hline $\begin{array}{l}\text { Lima bean } \\
(2006-009)\end{array}$ & $0.14 \pm 0.00$ & $0.36 \pm 0.00$ & $0.12 \pm 0.000$ & $0.69 \pm 0.00$ & $0.23 \pm 0.00$ & $48.95 \pm 0.35$ \\
\hline $\begin{array}{l}\text { Bambara } \\
\text { groundnut } \\
\text { (TVSU-1482) }\end{array}$ & $0.19 \pm 0.00$ & $0.38 \pm 0.00$ & $0.15 \pm 0.00$ & $1.12 \pm 0.00$ & $0.27 \pm 0.00$ & $57.95 \pm 0.35$ \\
\hline $\begin{array}{l}\text { Winged bean } \\
\text { (Tpt-48) }\end{array}$ & $0.16 \pm 0.00$ & $0.36 \pm 0.00$ & $0.12 \pm 0.00$ & $0.88 \pm 0.00$ & $0.23 \pm 0.00$ & $44.84 \underline{+0.03}$ \\
\hline $\begin{array}{l}\text { Jack bean } \\
(\text { Tce- } 4)\end{array}$ & $0.17 \pm 0.002$ & $0.36+0.002$ & $0.13 \underline{+0.002}$ & $0.91 \pm 0.002$ & $0.25 \pm 0.002$ & $51.60 \pm 0.14$ \\
\hline $\begin{array}{l}\text { Sword bean } \\
(\mathrm{Tcg}-4)\end{array}$ & $0.16 \underline{+0.002}$ & $0.37 \pm 0.002$ & $0.13 \pm 0.001$ & $0.89 \pm 0.002$ & $0.24 \underline{+0.002}$ & $53.45 \underline{+0.21}$ \\
\hline $\begin{array}{l}\text { African yam } \\
\text { bean } \\
\text { (TSS-95) }\end{array}$ & $0.23 \pm 0.0003$ & $0.20 \pm 0.0001$ & $0.35 \underline{+0.0006}$ & $0.72+0.0004$ & $\begin{array}{l}0.15 \pm 0.000 \\
2\end{array}$ & $80.98+0.0007$ \\
\hline
\end{tabular}

Mean \pm standard deviation

African yam bean. Source: Soetan (2017) 


\section{Soetan and Adeola}

The functional properties of the selected underutilized legumes are in Table 3. Bulk density ranged from $0.45 \pm 0.04 \mathrm{~g} / \mathrm{mL}$ (WB) to $0.77 \pm 0.08 \mathrm{~g} / \mathrm{mL}$ (SB), water absorption capacity ranged from $168.33 \pm 0.03 \mathrm{~g} / 100 \mathrm{~g}$ (LB) to $183.62 \pm 0.01 \mathrm{~g} / 100 \mathrm{~g}$ (SB), oil absorption capacity ranged from 146.54 $\pm 0.02 \mathrm{~g} / 100 \mathrm{~g}$ (LB) to $161.55 \pm 0.02 \mathrm{~g} / 100 \mathrm{~g}$ (JB), emulsion capacity ranged from 79.67 $\pm 0.02 \mathrm{~g} / 100 \mathrm{~g}$ (LB) to $89.46 \pm 0.02 \mathrm{~g} / 100 \mathrm{~g}$ (SB) and dispersibility ranged from $81.0 \pm 1.41 \%$ (SB) to $86.5 \pm 0.71 \%(\mathrm{BG})$.

Table 3: Functional properties of selected varieties of legumes

\begin{tabular}{lcllll}
\hline Varieties & $\begin{array}{l}\text { Bulk density } \\
(\mathbf{g} / \mathbf{m L})\end{array}$ & $\begin{array}{l}\text { Water } \\
\text { absorption } \\
\text { capacity }(\boldsymbol{\%})\end{array}$ & $\begin{array}{l}\text { Oil absorption } \\
\text { capacity }(\boldsymbol{\%})\end{array}$ & $\begin{array}{l}\text { Emulsifying } \\
\text { capacity }(\boldsymbol{\%})\end{array}$ & $\begin{array}{l}\text { Dispersibility } \\
(\boldsymbol{\%})\end{array}$ \\
\hline Lima bean (2006-009) & $0.53 \pm 0.04$ & $168.33 \pm 0.03$ & $146.54 \pm 0.02$ & $79.67 \pm 0.02$ & $85.0 \pm 1.41$ \\
Bambara groundnut (TVSU & $0.46 \pm 0.04$ & $176.30 \pm 0.02$ & $153.70 \pm 0.04$ & $83.75 \pm 0.02$ & $86.5 \pm 0.71$ \\
1482) & & & & & \\
Winged bean (Tpt-48) & $0.45 \pm 0.04$ & $171.46 \pm 0.01$ & $149.25 \pm 0.02$ & $81.56 \pm 0.02$ & $83.5 \pm 2.12$ \\
Jack bean (Tce-4) & $0.67 \pm 0.06$ & $182.44 \pm 0.02$ & $161.55 \pm 0.02$ & $87.35 \pm 0.01$ & $84.0 \pm 1.41$ \\
Sword bean (Tcg-4) & $0.77 \pm 0.08$ & $183.62 \pm 0.01$ & $154.27 \pm 0.02$ & $89.46 \pm 0.02$ & $81.0 \pm 1.41$ \\
African yam bean (TSS-95) & $0.67 \pm 0.06$ & $179.35 \pm 0.02$ & $158.66 \pm 0.02$ & $85.79 \pm 0.03$ & $85.0 \pm 1.41$ \\
\hline
\end{tabular}

Mean \pm standard deviation

Bulk density (BD), Water absorption capacity (WAC), Oil absorption capacity (OAC), Emulsifying capacity (EC), Dispersibility (D)

\section{Discussion}

Proximate analysis is an index to the nutritive value of human foods and animal feeds. It is a scheme of analysis which involves the estimation of the main composition of foods with the use of procedures that enable a reasonably acceptable and rapid measurement of food fractions (James, 1996). The increasing knowledge and awareness on the nutritional and functional properties of different food constituents has led to a greater body of information that is needed for particular foods (James, 1996). There are variations in the proximate compositions of all the underutilized legumes analysed in this study. The proximate composition for the selected underutilized legumes in this study compared favourably with that of different varieties of cowpea (Vigna unguiculata), a conventional legume, whose crude proteins ranged from $21.2 \%$ to $30.6 \%$ (Swaminathan and Jain, 1973; Ene-Obong and Carnovale, 1992; Eromosele et al. 2008; Inobeme et al., 2014), crude fat for cowpea ranged between $1.7 \pm 0.1 \%$ to $4.21 \pm 0.36 \%$ (Ene-Obong and Carnovale, 1992; Giami, 1993; Inobeme et al., 2014), crude fibre for cowpea ranged from $2.1 \pm 0.2 \%$ to $3.26 \pm 0.52 \%$ (Giami, 1993; Inobeme et al., 2014), ash for cowpea ranged from $3.1 \pm 0.2 \%$ to $4.50 \pm 0.10 \%$ (Ene-Obong and Carnovale, 1992; Giami, 1993; Inobeme et al., 2014), moisture content of cowpea ranged from $4.80 \pm 0.17 \%$ to $9.2 \pm 0.1 \%$ (Giami, 1993; Inobeme et al., 2014), the nitrogen free extracts (carbohydrates) of cowpea ranged from $59.9 \pm 0.7 \%$ to $62.68 \pm 0.58 \%$ (Giami, 1993; Inobeme et al., 2014). The nutritional and health importance of the proximate constituents of plants are well documented, proteins (Aremu et al., 2006; Okeke and Elekwa, 2006; Okeke et al., 2008), fats (Pamela et al., 2005), fibre (Okeke and Adaku, 2009; Soetan and Olaiya, 2013), ash (Musa et al., 2010), nitrogen free extracts (Okeke et al., 2008), moisture (Ajayi and Adedire, 2007; Okeke and Adaku, 2009) and energy contents of foods (Omoyeni and Adeyeye, 2009). 
Comparative nutritional and functional properties of selected underutilized legumes

The minerals constituents of the selected underutilized legumes also compared favourably with that of cowpea (Vigna unguiculata). Inobeme et al., (2014) reported calcium for cowpea to be within $194.12 \pm 0.12$ to $201.61 \pm 0.53(\mathrm{mg} / 100 \mathrm{~g})$, sodium $(78.12 \pm 0.85$ to $81.70 \pm 0.22$ $\mathrm{mg} / 100 \mathrm{~g})$, potassium $(733.03 \pm 0.34$ to $741.15 \pm 0.99 \mathrm{mg} / 100 \mathrm{~g}$ ), magnesium $(190.22 \pm 0.27$ to $195.02 \pm 0.10 \mathrm{mg} / 100 \mathrm{~g})$ and iron $(9.80 \pm 0.10$ to $10.11 \pm 0.9$ $\mathrm{mg} / 100 \mathrm{~g})$. However, Ene-Obong and Carnovale (1992) earlier reported different values, calcium (71.8 to $101 \mathrm{mg} / 100 \mathrm{~g}$ ), phosphorus (379 to $474 \mathrm{mg} / 100 \mathrm{~g}$ ), sodium (6.10 to $17.8 \mathrm{mg} / 100 \mathrm{~g}$ ), potassium (1271 to $1322 \mathrm{mg} / 100 \mathrm{~g}$ ) and iron (4.91 to 8.40 $\mathrm{mg} / 100 \mathrm{~g})$. The health benefits of the mineral elements have been reported, calcium (Seidu et al., 2014), phosphorus (Kalita et al., 2007), sodium (Twum et al., 2015), potassium (Murray et al. 2000), magnesium (Murray et al., 2000) and iron ((Antia et al., 2006). There is an increasing awareness of the role of mineral elements in human health and diseases (Gepts et al., 2005).

Functional properties of protein foods are important considerations in consumer acceptance (Mune and Sogi, 2016). The variation in the functional properties of the samples may be an indication of the different nature of proteins in the various pulses. Bulk density indicates the porosity of food and has been reported to influence packaging requirement of flours (Etudaiye et al., 2009). The bulk density reported for lima bean flour in this study was similar to the reported by Yellavila et al., (2015) for five accessions of lima seeds from Ghana. The bulk densities of the samples of NUS in this study were similar to the values of 0.67 $\mathrm{g} / \mathrm{mL}$ and $0.82 \mathrm{~g} / \mathrm{mL}$ reported by Wani (2015) for red cowpea flour and black cowpea flour respectively. However, Chima et al., (2008) reported lower range of
$0.29-0.40 \mathrm{~g} / \mathrm{mL}$ for certain varieties of cowpea. Food flour of higher bulk density would occupy less space per unit weight, resulting in lower packaging cost than flours with lower bulk density (Wani, 2015). Flour with low BD is preferred for complementary food preparation since it depicts less bulkiness and easy digestibility. BD is affected by the moisture content and particle size of food materials (Etudaiye et al., 2009). Water absorption capacity gives an indication of the starch structure as starch polymers with loose structure have been reported to possess high WAC (Etudaiye et al., 2009). The WAC capacity obtained for the samples were higher than $1.30 \mathrm{~mL} / \mathrm{g}$ (130\%) reported by Khalid and Elharadallou (2013) for cowpea flour but lower than the range of $1.89-2.15 \mathrm{~mL} / \mathrm{g}(189-215 \%)$ obtained by Appiah et al. (2011) for certain cowpea varieties. High WAC of the flour samples may mean high swelling power, and high peak viscosity, indicating that flours from these pulses may be desirable in baked foods (Buckman et al., 2017). High WAC enables bakers to conveniently manipulate the functional properties of doughs (Buckman et al., 2017). Flours with high WAC have also been reported to possess more hydrophilic constituents such as polysaccharides (Yellavila et al., 2015). The OAC which is an indication of the flavour retaining ability of food flour is higher among the samples investigated in this study than $1.04 \mathrm{~mL} / \mathrm{g}(104 \%)$ reported by Khalid and Elharadallou (2013) for cowpea flour but lower than the range of $1.95-2.31 \mathrm{~mL} / \mathrm{g}(195-231 \%)$ obtained by Appiah et al., (2011) for certain cowpea varieties. The OAC is a reflection of the emulsifying capacity and the amount of oil that can be picked up by food material during frying (Falade and Okafor, 2015). Eltayeb et al. (2011) reported $281.35 \%$ and $252.27 \%$ respectively for WAC and OAC 


\section{Soetan and Adeola}

of Bambara groundnut flour.

Emulsifying capacity measures the maximum amount of oil emulsified by protein in a given amount of flour. The emulsion capacity values obtained in this study were higher than the range (49.63$59.99 \%$ ) reported by Yellavila et al. (2015) for some varieties of lima bean seed, but lower than the range reported by Eltayeb et al. (2011) for bambara flour. This may be due to the difference in methods of analysis. Khalid and Elharadallou (2013) reported a range of 72.73-173.60 g oil/g sample at a $\mathrm{pH}$ of 2-12 for the emulsifying power of cowpea flour. The difference in EC may also be due to surface hydrophobicity (HO), ligand binding, molecular flexibility, and structure stability of the proteins (Mune and Sogi, 2016). Formation and stabilization of emulsions is critical in many applications, such as chopped and comminuted meats, cake batters, coffee whiteners, milk, mayonnaise, salad dressings, bakery products, and frozen desserts (Mune and Sogi, 2016). Dispersibility has been positively correlated with the ability of flour to reconstitute in water (Adebowale $e t$ al., 2005). The high dispersibility of the flour samples reinforced the earlier suggestion that they will be desirable in baked foods.

\section{Conclusion}

This study concluded that the selected underutilized legumes in this study; LB, $\mathrm{BG}, \mathrm{WB}, \mathrm{JB}, \mathrm{SB}$ and $\mathrm{AYB}$, all recorded good nutritional and functional proteins, many of which compared well with that of cowpea, a conventional legume. There is the need for more awareness and knowledge on other nutritional and health benefits of the underutilized legumes, so as to overcome the problem of food insecurity and nutritional-related diseases, especially in the developing countries.

\section{Acknowledgement}

The authors appreciate the Genetic Resources Unit (GRC) of the International Institute of Tropical Agriculture (IITA), Ibadan, Nigeria for providing all the underutilized legumes used for this study.

\section{References}

Adebowale, A. A., Sanni, L. O. and Awonorin, S. O. 2005. Effect of texture modifiers on the physicochemical and sensory properties of dried fufu. Food Science and Technology International 11(5):373-382.

Adebowale, K. O., Afolabi, T. A. and Olu-Owolabi, B. I. 2006. Functional, physicochemical and retrogradation properties of sword bean (Canavalia gladiata) acetylated and oxidized starches. Carbohydrate Polymers 65: 93-101.

Adewale, B. D. and Aremu, C. O. 2013. The nutritional potentials and possibilities in African yam bean for Africans. International Journal of AgriScience Vol. 3(1): 8-19.

Ajatta, M. A., Akinola, S. A. and Osundahunsi, O. F. 2016. Proximate, functional and pasting properties of composite flours made from wheat, breadfruit and cassava starch. Applied Tropical Agriculture 21(3): 158-165.

Ajayi, O. E. and Adedire, C. O. 2007. Nutrient characteristics of the subterranean termite, Macrotermes subhyalinus (Rambur) (Isoptera: Termitidae). Nigerian Journal of Entomology 24: 42-47.

Akinyosoye, S. T., Adetumbi, J. A., Amusa, O. D., Agbeleye, A., 
Comparative nutritional and functional properties of selected underutilized legumes

Anjorin, F., Olowolafe, M. O. and Omodele, T. 2017. Bivariate analysis of the genetic variability among some accessions of African Yam Bean [(Sphenostylis stenocarpa Hochst ex A. Rich) Harms]. Acta Agriculturae Slovenica, 109(3): 1-15.

Amoo, I. A., Adebayo, O. T. and Oyeleye, A. O. 2006. Chemical evaluation of winged beans (Psophocarpus tetragonolobus), pitanga cherries (Eugenia uniflora) and orchid fruit (orchid fruit myristica). Afican Journal of Food Agriculture Nutrition and Development 6(2): 1-12.

Antia, B. S., Akpan, E. J., Okon, P. A. and Umoren, I. U. 2006. Nutritive and anti-nutritive evaluation of sweet potatoes (Ipomoea batatas) leaves. Pakistan Journal of Nutrition 5(2): 166- 168.

AOAC (Association of Official Analytical Chemists) 2000 . "Official Method of Analysis" 4th Edition (129-135), Washington D.C.U.S.A.

Appiah, F., Asibuo, J. Y. and Kumah, P. 2011. Physicochemical and functional properties of bean flours of three cowpea (Vigna unguiculata $\mathrm{L}$. Walp) varieties in Ghana. African Journal of Food Science Vol. 5(2): 100 - 104.

Aremu, M. O., Olaofe, O. and Akintayo, E. T. 2006. Compositional evaluation of cowpea (Vigna unquiculata) and scarlet runner bean (Phaseolus coccineus) varieties grown in Nigeria. Journal of Food Agriculture and Environment 4(2): 39-43.

Asif, M., Rooney, L. W., Ali, R. and Riaz, M. 2013. Application and opportunities of pulses in food system: A review. Critical Reviews in Food Science and Nutrition 53:1168-1179.

Ayo, J. A., Popoola, C. A., Ayo, V. A. and Andrew, E. 2014. Effect of added bambara groundnut flour on the quality of 'acha' based 'fura'. British Journal of Applied Science and Technology 4(1): 168-176.

Buckman, E. S., Oduro, I. A., Plahar, W. and Tortoe, C. 2017 . Determination of the chemical and functional properties of yam bean (Pachyrhizus erosus (L.) Urban) flour for food systems. Food Science and Nutrition. (In Press). DOI: 10.1002/fsn3.574.

Chinma, C. E., Emelife, I. C. and Alemede, I. G. 2008 . Physicochemical and functional properties of some Nigerian cowpea varieties. Pakistan Journal of Nutrition 7: 186-190. A va i l a ble online: http://dx.doi.org/10.3923/pjn.20 $\underline{08.186 .190}$

Coffman, C. W. and Garcia, V. V. 1977. Functional Properties and Amino Acid Contents of Protein Isolate from Mung Bean Flour. Journal of Food Technology 12:473-484.

Ene-Obong, H. N. and Carnovale, E. 1992. A comparison of the proximate, mineral and amino acid composition of some known and lesser-known legumes in Nigeria. Food Chemistry 43: 169175.

Eltayeb, A. R. S. M., Ali, A. O., AbouArab, A. A. and Abu-Salem, F. M. 2011. Chemical composition and functional properties of flour and protein isolate extracted from bambara groundnut (Vigna subterranean). African Journal of 


\section{Soetan and Adeola}

Food Science Vol. 5(2): 82 -90.

Etudaiye, H. A., Nwabueze, T. U. and Sanni, L. O. 2009. Pasting and functional properties of processed $f u f u$ from cassava mosaic disease-resistant varieties cultivated in a high rainfall zone. Nigerian Food Journal 27 (2): 185-193.

Falade, K. O. and Okafor, C. A. 2015. Physical, functional, and pasting properties of flours from corms of two Cocoyam (Colocasia esculenta and Xanthosoma sagittifolium) cultivars. Journal of Food Science and Technology 52(6):3440-3448.

Gepts, P., Beavis, W. D., Brummer, E. C., Shoemaker, R. C., Stalker, H. T., Weeden, N. F. and Young, N. D. 2005. Legumes as a model plant family. Genomics for food and feed report of the crosslegume advances through genomics conference. Plant Physiology 137: 1228-1235.

Giami, S. Y. 1993. Effect of processing on the proximate composition and functional properties of cowpea (Vigna unguiculata) flour. Food Chemistry 47: 153-158.

Hamid, S., Muzzafar, S., Wani, A. I. and Masoodi, F. A. 2015. Physicochemical and functional properties of two cowpea cultivars grown in temperate Indian climate. Cogent Food and Agriculture 1: 109-114.

Ikhajiagbe, B. and Mensah, J. K. 2012. Genetic assessment of three colour varaints of African yam beans (Sphenostylis stenocarpa) commonly grown in Mideastern region of Nigeria. International Journal of Modern Botany 2 (2): 13-18.

Inobeme, A., Nlemadim, A. B., Obigwa,
P. A., Ikechukwu, G. and Ajai, A. I. 2014. Determination of Proximate and Mineral Compositions of White Cowpea beans (Vigna unguiculata) collected from markets in Minna, Nigeria. International Journal of Scientific and Engineering Research 5(8): 502-504.

Jaenicke, H. and Pasiecznik, N. 2009. Making most of underutilized crops. LEISA Magazine, 25:11 12

James, C. S. 1996. Analytical Chemistry of Foods. Blackie Academic and Professional (Chapman and Hall), Bishopbriggs, Glasgow G64 2NZ.

Kalita S J, Bhardwaj A. and Bhatt, H.A. 2007. Nanocrystalline calcium phosphate ceramics in biomedical engineering. Materials Science and Engineering: C, 27(3): 441449.

Khalid, I. I. and Elharadallou, S. B. 2013. Functional Properties of Cowpea (Vigna Ungiculata L.Walp), and Lupin (Lupinus Termis) Flour and Protein Isolates. Journal of Nutrition and Food Science 3: 234. doi: 10.4172/21559600.1000234

Kulkarni, K. D., Kulkarni, D. N., and Ingle, U. M. 1991. Sorghum Malted and Soya Bean Weaning Food Formulations: Preparation, Functional Properties and Nutritive Value. Food and Nutrition Bulletin 13: 322-327.

Marimuthu, M. and Gurumoorthi, P. 2013. Physicochemical and functional properties of starches from Indian Jack bean (Canavalia ensiformis), an underutilized wild food legume. Journal of Chemical and Pharmaceutical Research 5(1): 221-225. 
Mune, A. A. M. and Sogi, D. S. 2016. Emulsifying and foaming properties of protein concentrates prepared from cowpea and bambara bean using different drying methods. International Journal of Food Properties 19: 371-384.

Murray, R. K., Granner, D. K., Mayes, P. A. and Rodwell, V. W. 2000. Harper's Biochemistry, 25th Edition, McGraw-Hill, Health Profession Division, USA.

Musa, A. K., Kalejaiye, D. M., Ismail, L. E. and Oyerinde, A. A. 2010. Proximate composition of selected groundnut varieties and their susceptibility to Trogoderma granarium Everts attack . Journal of Stored Products and Post Harvest Researh 1(2): 13-17.

Naylor, R. L, Falcon, W. P, Goodman, R. M. Jahn, M. M., Sengooba, T., Tefera, H. and Nelson, R. J. 2004. Biotechnology in the developing world: a case for increased investment in orphan crops, Food Policy 29:15-44.

Obasi, N. E., Uchechukwu, N. and EkeObia, E. 2012. Production and evaluation of biscuits from African yam bean (Sphenostylis stenocarpa) and wheat (Triticum aestivum) flours. Food Science and Quality Management 7: 5-12.

Ojo, M. A. 2013. Effect of trona on the nutritional status of Vigna racemosa during cooking. Proceedings of the $37^{\text {th }}$ Annual Conference, Nigerian Institute of Food Science and Technology, Abuja 178-179.

Ojo, M. A., Ade-Omowaye, B. I. and Ngoddy, P. O. 2016. Mineral elements in Canavalia ensiformis: influence of hydrothermal processing techniques. Annals Food Science and Technology 17(2): 548-555.

Okeke, C. U. and Adaku, C. N. 2009. Phytochemical and Proximate Analyses of Euphorbia he terophylla Lin . (Euphorbiaceae). Nigerian Journal of Botany 22(1): 215222.

Okeke, C. U. and Elekwa, I. 2006. Proximate and Preliminary Phytochemical analyses of Avocado pear, Persea gratissima Gaertn. F. (Family Lauraceae). Nigerian Journal of Botany 19(1): 156-162.

Okeke, C. U., Izundu, A. I. and Uzoechina, E. 2008 . Phytochemical and Proximate study of female pawpaw (Carica papaya Linn.) Caricaceae. Journal of Science, Engineering and Technology 15(2): 82078216.

Okigbo, B. N. 1973. Introducing the yam bean (Sphenostylis stenocarpa) (Hochst ex. A. Rich.) Harms. Proceedings of the first IITA Grain Legume Improvement Workshop 29 October to 2 November 1973 Ibadan. Nigeria.

Omoyeni, O. A. and Adeyeye, E. I. 2009. Chemical composition, calcium, zinc and phytate. inter relationships in Aerva lanata (Linn) Juss. Ex Schult Leaves. Orient Journal of Chemistry 25: 485-488.

Oniang'o, R. K., Shiundu, K., Maundu, P. and Johns, T. 2006. Diversity, nutrition and food security: the case of African leafy vegetables. In: Ravi, S. B., HoeschleZeledon, I.; Swaminathan, M. S. and Frison, E. (ed.). Hunger and Poverty: the role of biodiversity. 
Report of an International Consultation on the role of Biodiversity in 164 achieving the UN Millennium Development Goal of freedom from hunger and poverty. Chennai, India, April 18 - 19, 2005. M. S. Swaminathan Research Foundation, India.

Onwuka, G. I. 2005. Food Analysis and Instrumentation: Theory and Practice. Naphtali Prints, Lagos, Nigeria. pp 104-149.

Padulosi, S., Noun, J., Giuliani, A., Shuman, F., Rojas, W. and Ravi, B. 2003. Realizing the benefits in Neglected underutilized plant species through technology transfer and human resources development. Norway/UN Conference on Technology Transfer and Capacity Building.

Pamela, C.C., Richard, A.H. and Denise, R.F. 2005. Lippincotts illustrated reviews in biochemistry. 3rd edition, Lippincott Williams and Wilkins, Philadelphia, pp. 335388. ISBN-13: 978-1451175622.

Roba, A. C., Gabriel-Micheal, K., Zello, G. A., Jaffe, J., Whiting, S. J. and Henry, C. J. 2015. A low pulse food intake may contribute to the poor nutritional status and low dietary intakes of adolescent girls in rural southern Ethiopia. Ecology of Food and Nutrition 54(3): 240-254.

Seidu, K. T., Osundahunsi, O. F., Olaleye, M. T. and Oluwalana, I. B. 2014 . Chemical composition, phytochemical constituents and antioxidant potentials of Lima bean seeds coat. Annals Food Science and Technology 15(2): 288-298.

Soetan, K. O. 2017. Preliminary Studies on the Nutritional and
Antinutritional Constituents of Six Accessions of African Yam Bean (Sphenostylis stenocarpa), an Underutilized Legume. Annals of Food Science and Technology 18(4): 625-631.

Soetan, K. O and Olaiya, C. O. 2013. Summarizing Evidence Based Information on the Medical Importance of Dietary Fibre. Annals of Food Science and Technology 14(2): 393-399.

Stifel, L. D. 1990. The Genetic Resources. In: Ng NQ, Monti LM (ed) Cowpea genetic Resource. International Institute of Tropical Agriculture, Ibadan.

Swaminathan, M. S. and Jain, H. K. 1973. Food legumes in India Agriculture, In: National Improvement of Food legumes by breeding. Protein Advisory Group, United Nations, New York, pp. 69-82.

Twum, L. A., Okyere, A. A., Asare, I. K., Kottoh, I. D., Duah-Bisiw, D., Torgby-Tetteh, W. and Ayeh, E. A. 2015. Physicochemical and Functional Quality of Tigernut Tubers (Cyperus esculentus) Composite Flour. British Journal of Applied Science and Technology 11(3): 1-9.

Wang, T. and Kinsella, J. E. 1976. Functional properties of novel proteins; alfalfa leaf protein. Journal of Food Science 41:18-23.

Yellavila, S. B., Agbenorhevi, J. K., Asibuo, J. Y. and Sampson, G. O. 2015 . Proximate composition, minerals content and functional properties of five lima bean accessions. Journal of Food Security 3(3): 69-74.

Received: $10^{\text {th }}$ January, 2018

Accepted: $12^{\text {th }}$ May, 2018 